\title{
Genetic variability for Yield and Yield Related Traits in Orange-fleshed Sweetpotato Genotypes Evaluated at Hawassa, Ethiopia
}

\author{
Bililign Mekonnen $^{1,}$, , Andargachew Gedebo ${ }^{2}$, Fekadu Gurmu ${ }^{1}$ \\ ${ }^{1}$ Hawassa Research Centre, Hawassa, Ethiopia \\ ${ }^{2}$ College of Agriculture, Hawassa University, Hawassa, Ethiopia
}

Email address:

bililign.m@gmail.com (B. Mekonnen)

${ }^{*}$ Corresponding author

To cite this article:

Bililign Mekonnen, Andargachew Gedebo, Fekadu Gurmu. Genetic variability for Yield and Yield Related Traits in Orange-fleshed Sweetpotato Genotypes Evaluated at Hawassa, Ethiopia. Agriculture, Forestry and Fisheries. Vol. 10, No. 1, 2021, pp. $28-35$. doi: $10.11648 /$ j.aff.20211001.15

Received: December 17, 2020; Accepted: December 28, 2020; Published: March 10, 2021

\begin{abstract}
The study was conducted to determine variability for yield and yield related traits in 24 orange fleshed sweetpotato [Ipomoea batatas (L.) Lam] genotypes in the 2017 main cropping season at Hawassa Agricultural Research Center. The experiment was laid out in a Randomized Complete Block Design with three replications. Data were collected on 19 traits and analysis of variance (ANOVA) was conducted. Significant differences $(\mathrm{p} \leq 0.05)$ among genotypes were observed for root yield and its components as well as morphological and qualitative traits including sweetpotato virus disease reaction (SPVD). The phenotypic coefficient of variation (PCV) ranged from $22.1 \%$ for mature leaf size to $118.3 \%$ for unmarketable root yield, while the genotypic coefficient of variation (GCV) ranged from $20.6 \%$ for root girth to $111.7 \%$ for unmarketable root yield. All the traits studied showed PCV and GCV more than 20\%, suggesting high variability and this could be used for the selection of superior genotypes concerning character of interest. Most traits showed high values for broad-sense heritability, which ranged from 66.7 to $100 \%$, indicating low environmental influence in the observed variation. High heritability coupled with high genetic advances as a percent of mean was observed for marketable root yield, root skin color, root beta carotene content, harvest index, vine length, vine inter-node length and above ground fresh weight, implying these characters are governed by additive gene action and selection would be rewarding for the further improvement of such traits.
\end{abstract}

Keywords: Genotypes, Heritability, Orange Fleshed Sweetpotato, Variability, Yield

\section{Introduction}

Sweetpotato is an economically important crop in tropical, subtropical and warm temperate regions [18]. Chiefly, Orange fleshed sweetpotato [Ipomoea batatas (L) Lam.] is considered as a helpful crop in the fight against malnutrition (Vitamin A deficiency) in Africa. It is crosspollinated (self-incompatible) and, therefore, highly heterozygous crops in which many of the traits show continuous variation. Since it is highly heterozygous, there is extensive variability within the species, which is available for exploitation by plant breeders [25]. On top of this, the availability of morpho-genetic variation in agronomic characters of the crop would be of considerable importance in determining the best method to improve the crop yield. Genetic improvement of any crop requires knowledge of the nature and magnitude of variability in the base population [7]. Also, it is necessary to generate information on the relative contribution of the various component traits to yield and the identification of superior yielding genotypes from genetically variable populations [26]. However, so far, there is little information on the variability and character association study among sweetpotato varieties in Ethiopia [11]. Therefore, this study was initiated to assess variability in orange fleshed sweetpotato genotypes to exploit the genetic potential of sweetpotato genotypes for further improvement program. 


\section{Materials and Methods}

\subsection{Description of the Experimental Site}

The experiment was conducted during the 2017 main rainy season under the rain-fed condition at Hawassa Agricultural Research Center (HARC). HARC is located in Hawassa city $\left(7^{\circ} 04^{\prime} \mathrm{N}, 38^{\circ} 31^{\prime} \mathrm{E}, 1700 \mathrm{~m}\right.$ above sea level, the average annual rain- fall of the area is $1141 \mathrm{~mm}$, minimum/maximum air temperature is $13.1 / 27.1^{\circ} \mathrm{C}$ respectively), the capital of Southern Nations, Nationalities, and Peoples' Regional State (SNNPRS), in the southern part of Ethiopia. The soil is volcanic in origin and is classified as Vitric Andosol. The textural class is a well- drained sandy loam with a $\mathrm{pH}$ of 7 [6].

\subsection{Experimental Materials}

Twenty four orange fleshed sweetpotato genotypes were used for the study, among which two released varieties in Ethiopia included as checks (Kulfo and Tula). The four genotypes are advanced lines from HwARC crosses and the rest are introduced from Kenya, Uganda and Mozambique.

\subsection{Experimental Design and Field Management}

The experiment was planted under a Randomized Complete Block Design (RCBD) three replications. The experimental plot size was $7.2 \mathrm{~m}^{2}$, with $3 \mathrm{~m}$ long and $2.4 \mathrm{~m}$ width. Each plot consisted of four rows (ridges), with ten plants per row. The spacing between rows and between plants within a row was 60 and $30 \mathrm{~cm}$, respectively. The spacing between blocks was 2 meter. Ten holes per row and 40 per plot were prepared and one vine cutting of $30 \mathrm{~cm}$ in length was planted in each hole of the row (ridge). The genotypes were planted on 8 Aug 2017. All plots received the recommended [4] cultural practices uniformly and no fertilizer was applied. Replanting was done to substitute the dead vine after one week of planting. Earthning-up was done after the fourth week of planting and all plots were kept weed free by regular weeding and cultivation. Harvesting was done on 28 Dec 2017 after sweetpotato leaves changed to yellowish color.

\subsection{Data Collection}

Data collected from the two central rows, excluding the two plants grown at both ends of the row and the two border rows.

\subsubsection{Growth and Morphological Characteristics}

Vine length $(\mathrm{cm})$ : measured by taking the vertical length of the vine from the ground level to the tip of the main shoot of the plants by using five plants randomly taken from each plot and averaged over the plants. Vine inter-nodal length $(\mathrm{cm})$ : is the measured value between two successive nodes. It was measured using three internodes (node numbers) located in the middle section of the vine of five randomly selected plants in a plot and was expressed in centimeter. Mature leaf size (cm): Three leaves located in the middle section of the vine were measured from the basal lobes to the tip (apex) of the leaves and averaged over the sampled numbers per plot. Vine girth $(\mathrm{mm})$ : the mean diameter of the vine from the central portion of the main shoot. The girth/diameter of each of the five sampled plants was measured by caliper and then divided by the number of plants and expressed in centimeter. Petiole length $(\mathrm{cm})$ : The petiole length was measured from the base to the insertion point with the blade. Data taken from five randomly selected plants and expressed in centimeter. Ground cover: Estimations of ground cover were recorded 60 days after planting and levels were considered as low with $<50 \%$ ground cover, medium with $50-74 \%$ ground cover, high with $75-90 \%$ ground cover and very high with $>90 \%$ ground cover [13].

\subsubsection{Yield and Yield Related Traits}

Number of storage roots per plant: is the mean number of storage roots produced by the sampled plants. The total number of storage roots from each of the sampled plants was counted and divided by the number of plants and expressed as number per plant. Storage root length $(\mathrm{cm})$ : is the length of storage root that was measured from distal to the proximal end on five randomly taken plants at harvest. Storage root girth: is the diameter from the middle portion of the storage root. The girth of all the storage roots of each of the sampled plants was measured by using a caliper and divided by the number of storage roots from all plants sampled and expressed in centimeter. Aboveground fresh weight $\left(\mathrm{t} \mathrm{ha}^{-1}\right)$ : The weight of the above- ground parts of the two central rows was taken and converted to $\mathrm{t} / \mathrm{ha}$. Harvest index (HI): it was calculated as a ratio of economic yield (fresh root weight) to the total weight/biological yield (above ground fresh weight + fresh root weight) on fresh weight basis

$$
\text { Harvest Index }=\frac{\text { Economical Yield }}{\text { Biological Yield }} * 100
$$

Marketable yield ( $\left.\mathrm{t} \mathrm{ha}{ }^{-1}\right)$ : the weight of clean, uninfected storage roots that fall in size range of $100 \mathrm{~g}-500 \mathrm{~g}$. It was taken by weighing all the storage roots collected from the harvestable plot by using beam balance and expressed as $\mathrm{t} \mathrm{ha}^{-1}$. Unmarketable yield ( $\mathrm{t} \mathrm{ha}^{-1}$ ): the weight of infested, under- sized (less than 100g), over- sized (more than $500 \mathrm{~g}$ ) bruised, or cut storage roots. It was taken by weighting all the storage roots collected from the harvestable plot by using beam balance. It was expressed as $t \mathrm{ha}^{-1}$. Total storage root yield $\left(\mathrm{t} \mathrm{ha}^{-1}\right)$ : is the sum total of both marketable and unmarketable storage root yields obtained from the harvestable plot. And then it was expressed as $\mathrm{t} \mathrm{ha}^{-1}$. Yield per hectare: this was obtained from the harvestable plot (net plot) and converted in to yield per hectare by using the formula written below and was expressed as a ton per hectare

$$
\text { Yield per hectare in tones }=\frac{\text { Yield per net plot }(\mathrm{kg}) \times 10,000}{\text { Net area of the plot }\left(\mathrm{m}^{2}\right) \times 1000}
$$

\subsubsection{Qualitative Data}

Sweetpotato Virus Disease (SPVD): - recorded on a plot basis, using a scale of 1 to 5 , where $1=$ no visible symptoms, $2=$ mild symptoms (a few local lesions on a few leaves), $3=$ moderate symptoms (mosaic symptoms on leaves), $4=$ severe symptoms (mosaic symptoms with plants showing stunted growth) and $5=$ very severe symptoms of 
purpling/yellowing or mosaic on leaves, severe leaf distortion, reduced leaf size and severe stunting [22]. Predominant skin colour: - recorded on a scale of 1-9 as described by [13], where $1=$ White, $2=$ Cream, $3=$ Yellow, 4=Orange, $5=$ Brownish orange, 6=Pink, 7=Red, 8=Purple- red, and 9=Dark Purple [13]. Predominant flesh colour: recorded in scale of 1-9 as described by [13], where $1=$ White, $2=$ Cream, $3=$ Dark cream, 4=Pale yellow, $5=$ Dark yellow, $6=$ Pale orange, $7=$ Intermediate orange, $8=$ Dark orange, and 9=Strongly pigmented with anthocyanin [13]. $\beta$-carotene content: was estimated based on a colour chart developed by [2]. Root dry matter content (RDMC):-expressed as a percentage of root dry weight $(\mathrm{g})$ to fresh root weight $(\mathrm{g})$. $200 \mathrm{~g}$ samples were taken from roots of sampled plants in the plot and the samples were dried in an oven at $80^{\circ} \mathrm{C}$ for 48 hours to maintain a constant weight. The weight was taken by using sensitive balance and the ratio was expressed in percent.

\subsection{Data Analysis}

All collected data were subjected to ANOVA using SAS statistical package (SAS 9.0) and Minitab software version 16. Duncan's multiple range tests were employed to compare means at $5 \%$ probability levels, as described by [10].

Model for RCBD: $Y i j=\mu+\beta j+\mathrm{T} i+$ random error

Yij=any observation for which $i$ is the treatment factor, $j$ is the blocking factor

$\mathrm{Ti}=$ is the effect for being in treatment $i$

$\mu=$ the mean

$\beta \mathrm{j}=\mathrm{is}$ the effect for being in block $j$

Analysis of genetic parameters

The phenotypic, genotypic and environmental variances and coefficient of variations were calculated according to the formula suggested by [27] using the ANOVA table of Randomized Complete Block Design (RCBD).
Environmental variance $\left(\sigma^{2} \mathrm{e}\right),=\mathrm{MSe}$,

$$
\text { Genotypic variance }\left(\sigma^{2} g\right)=\frac{M s g-M s e}{r}
$$

Phenotypic variance $\left(\sigma^{2} p\right)=\sigma^{2} g+M S e / r$

$$
\begin{aligned}
& \text { Phenotypic coefficient of variation }(\mathrm{PCV})=\frac{\sqrt{\sigma 2 \mathrm{p}}}{\overline{\mathrm{x}}} * 100 \\
& \text { Genotypic coefficient of variation }(\mathrm{GCV})=\frac{\sqrt{\sigma 2 \mathrm{~g}}}{\overline{\mathrm{x}}} * 100
\end{aligned}
$$

Where, $\mathrm{MS}_{\mathrm{g}}$ is the mean square due to genotypes; $\mathrm{MS}_{\mathrm{e}}$ is the mean square of error (Environmental variance) $r$ is the number of replications; $\sigma^{2} \mathrm{~g}$ is genotypic variance and $\sigma^{2} \mathrm{e}$ is environmental variance; $\sigma^{2} \mathrm{p}=$ Phenotypic variation; $\overline{\mathrm{x}}=$ Grand mean of the characters considered

$\mathrm{PCV}=$ phenotypic coefficient of variation; $\mathrm{GCV}^{=}$genotypic coefficient of variation

$\mathrm{H}^{2}=\sigma^{2} \mathrm{~g} / \sigma^{2} \mathrm{p}^{*} 100$; Where, $\mathrm{H}^{2}=$ Heritability in broad sense; $\sigma 2 \mathrm{~g}=$ genotypic variance

$\sigma^{2} p=$ phenotypic variance;

The trait heritability was categorized as low $(<50 \%)$, moderate $(50-70 \%)$ and high $(>70 \%)$, as suggested by [24].

$\mathrm{GA}=\mathrm{KH}^{2} . \sigma \mathrm{p}$; Where, $\mathrm{GA}=$ Expected genetic advance, $\mathrm{H}^{2}=$ Heritability in broad sense, $\sigma \mathrm{p}=$ Phenotypic standard deviation, $\mathrm{k}=$ the standardized selection differential at $5 \%$ selection intensity $(\mathrm{K}=2.06)$

\section{Results and Discussion}

\subsection{Analysis of Variance for 19 Traits of OFSP Genotypes}

Analysis of Variance (ANOVA) showed the presence of a highly significant difference $(p<0.01)$ among the tested

\begin{tabular}{|c|c|c|c|c|}
\hline No. & Traits & Mean square Replication (df=2) & Genotype $(\mathrm{df}=\mathbf{2 3})$ & Error $(d f=48)$ \\
\hline 1 & GC & 48.98 & $936.18^{* *}$ & 19.39 \\
\hline 2 & SPVD & 0.38 & $1.57^{* *}$ & 0.22 \\
\hline 3 & VL & 231.30 & $4640.30^{* *}$ & 167.10 \\
\hline 4 & IL & 0.77 & $6.58^{* *}$ & 0.38 \\
\hline 5 & VD & 0.51 & $2.72^{* *}$ & 0.26 \\
\hline 6 & PL & 18.73 & $104.87^{* *}$ & 6.71 \\
\hline 7 & MLS & 0.10 & $7.15^{* *}$ & 0.86 \\
\hline 8 & RL & 0.97 & $16.51^{* *}$ & 3.92 \\
\hline 9 & RG & 2.12 & $1.16^{* *}$ & 0.58 \\
\hline 10 & AGFW & 2.14 & $480.94^{* *}$ & 71.21 \\
\hline 11 & HI & 0.00 & $0.03^{* *}$ & 0.00 \\
\hline 12 & RDMC & 0.14 & $46.27^{* *}$ & 0.39 \\
\hline 13 & RBCC & 0.43 & $35.94^{* *}$ & 0.19 \\
\hline 14 & $\mathrm{SC}$ & 0.00 & $16.95^{* *}$ & 0.00 \\
\hline 15 & $\mathrm{FC}$ & 0.26 & $9.33^{* *}$ & 9.33 \\
\hline 16 & NRP & 0.01 & $0.05^{* *}$ & 0.02 \\
\hline 17 & MRKY & 1.61 & $100.33^{* *}$ & 9.12 \\
\hline 18 & UMRKY & 1.63 & $8.68^{* *}$ & 2.85 \\
\hline 19 & TYLD & 3.42 & $129.09^{* *}$ & 10.45 \\
\hline
\end{tabular}
genotypes for yield and its contributing traits studied (Table 1).

Table 1. Analysis of variance for 19 traits of OFSP genotypes

Note. ** Significant at $0.1 \%$; d.f $=$ degree of freedom, $\mathrm{GC}=$ Ground cover, $\mathrm{SPVD}=\mathrm{Sweetpotato}$ virus disease, $\mathrm{VL}=\mathrm{Vine}$ length, $\mathrm{IL}=\mathrm{Vine}$ inter-node length, $\mathrm{VD}=$ Vine diameter, $\mathrm{PL}=$ Petiole length, $\mathrm{MLS}=$ Mature leaf size, $\mathrm{RL}=$ Root length, $\mathrm{RG}=$ Root girth, $\mathrm{AGFW}=\mathrm{Above}$ ground fresh weight, $\mathrm{HI}=\mathrm{Harvest}$ index, $\mathrm{RDMC}=$ Root dry matter content, $\mathrm{RBCC}=$ Root beta carotene content, $\mathrm{SC}=$ Skin colour, $\mathrm{FC}=\mathrm{Flesh}$ colour, $\mathrm{NRP}=\mathrm{Number}$ of roots per plant, $\mathrm{MRKY}=\mathrm{Marketable}$ root yield, UMRKY=Unmarketable root yield, TYLD=Total storage root yield. 


\subsection{Mean Performance of Genotypes for Yield and Its Contributing Traits}

The mean performance of the genotypes for root length ranged from 9 to $18.1 \mathrm{~cm}$ with over all mean of $14.7 \mathrm{~cm}$. Genotype G1 (Ukr/Eju-10) showed the highest mean root length of $18.1 \mathrm{~cm}$ while genotypes G24 (Tula) and G23 (Kulfo) showed the lowest mean root length performance of $9,9.5 \mathrm{~cm}$, respectively. The high root girth values were recorded for genotypes: G19, G15, G20, G21, G10, G13, G1, G11, and G23 with an average mean of more than $5.1 \mathrm{~cm}$, respectively (Table 3 ). The lowest root girth values were recorded for genotypes G4, G12 and G16 with a mean value of 3.4, 3.8 and $3.8 \mathrm{~cm}$, respectively. Genotype G14 (Mayai) and G17 (Tomulabula) showed the highest above- the ground fresh weight of 75.1 and $63.7 \mathrm{t} \mathrm{ha}^{-1}$, respectively (Table 3 ). Genotypes with high value of above the ground fresh weight can be used as the potential genotypes for further improvements as a source of animal feed. Whereas, genotype G23 (Kulfo) showed the lowest mean performance of $17.4 \mathrm{t}$ $\mathrm{ha}^{-1}$ (Table 3). The highest and lowest mean values of number of roots per plant was obtained 0.7 for G19 (Melinda) and 0.2 for G24 (Tula). The highest marketable roots were obtained from genotypes G22 (Jane) and G19 (Melinda) with 23.5 and $22.0 \mathrm{t} \mathrm{ha}^{-1}$, respectively, indicating that they are better genotypes with less wastage.

On the other hand, the lowest marketable roots were recorded for genotypes G4 (Res/Tem-23), G23 (Kulfo) and G24 (Tula) with a mean yield of 5.0, 5.0 and 5.4 tha $\mathrm{th}^{-1}$ in that order. The mean of unmarketable root yield was ranged from 0.2 (G10) to $6.5(\mathrm{G} 24) \mathrm{t} \mathrm{ha}^{-1}$. This genotype is not a good type for producing sweetpotato for marketing roots.

The highest total storage root yield was obtained from G10 $\left(27.4 \mathrm{t} \mathrm{ha}^{-1}\right)$, while the lowest total storage root yield was obtained from G24 $\left(5.7 \mathrm{t} \mathrm{ha}^{-1}\right)$ (Table 3). Genotypes: G10, G9, G11, G15 and G19 had the highest harvest index of 45, 44, 42, 41 and $41 \%$, respectively. The harvest index of the tested genotypes ranged from $13 \%$ for G4 to $45 \%$ for G10, with an average of $29 \%$. The harvest index showed the ratio of assimilation distribution between the economic and the overall biomass [9]. The High harvest index shows the efficiency of the assimilate utilization, which could be seen from the high production point of view. This was confirmed by genotype G10 that offered the highest harvest index (0.45), which also had the highest storage root yield (27.4 t $\mathrm{ha}^{-1}$ ). However, this genotype showed low above-ground fresh weight. As a result, the high HI values were not only due to its high fresh root yield but also due to its low aboveground fresh weight. This suggests that high correlation between yield and HI does not necessarily imply that HI could be an effective selection criterion for high yield in all situations, as suggested by [16]. The root dry matter content was ranged from 20 to $33 \%$. And nearly $50 \%$ of the tested genotypes expressed the root dry matter content of more than 30\%. Especially, genotypes G3 (Res/Tem-14), G21 (Gloria) and G1 (Ukr/Eju-10) showed high mean dry matter contents of $33,32.6$ and $31.9 \%$, respectively, indicating that these genotypes could solve the acceptability problem of the previously released OFSP varieties that had low root dry matter contents. This is because root dry matter content is an important and most preferred market attribute and is one of the criteria farmers use in selecting sweetpotato cultivars, as suggested by $[29,12]$.

\subsection{Mean Performance of the Genotypes in Morphological, Qualitative Traits and SPVD Reaction}

Mature leaf size varied among the genotypes from $9.7 \mathrm{~cm}$ for G19 (Melinda) to $14.8 \mathrm{~cm}$ for G17 (Tomulabula) with the overall mean of $12.1 \mathrm{~cm}$. Genotypes with large leaf sizes can easily trap sunlight and hence carry out better photosynthesis required for carbohydrates synthesis than those with small leaf size (high water consumption is also observed). Ground cover is the function of these characters and it varied among the genotypes where three genotypes (G20, G22 and G24) showed low ground cover. These genotypes showed below $50 \%$ of ground cover estimates (IPGRI, 1991). Conversely, genotypes: G1, G2, G3, G4, G7, G17, G18, G21, and G23 attained 50-74\% ground cover; these genotypes were considered as medium types [13]. Twelve genotypes had showed high ground cover (75-90\%) after a 35-40 day of planting. A High ground cover estimate indicates early coverage of the ground and subsequent suppression of weeds (water evaporation from the soil). This has practical significance as weeds compete for light, water and nutrients. Genotype G4 had the highest mean inter-node length of $8.3 \mathrm{~mm}$, whereas, genotype G24 (Tula) had the lowest mean inter-node length $(1.7 \mathrm{~mm})$. The longest vine length $(193.2 \mathrm{~cm})$ was recorded for the genotype designated as $\mathrm{G} 4$, which had a spreading growth habit while the shortest vine length $(49.3 \mathrm{~cm})$ was obtained for genotype G10, which was an erect type.

This implying that in addition to storage root yield benefits obtained from these genotypes, their long vine could be used as a good source of planting material. Similar to this study, [15] indicated that sweetpotato vines are used as forage for ruminants due to their richness in protein and minerals. The authors also, reported a significant differences among sweet potato genotypes for vine length, growth rate, leaf area and tuber yield in sweetpotato.

The highest skin color score (9.0) was recorded for genotypes G9, G10 and G15; these genotypes had a dark purple skin color. While the lowest skin color score (2.0) was recorded for genotypes: G1, G3, G8, G12, G13, G14, G18, $\mathrm{G} 19$, and G21. This indicates that most of the studied genotypes had cream skin color. For flesh color, the highest mean value (8.0) was recorded for G4, G6, G11, G13 and G15, where these genotypes had dark orange flesh color indicating their high beta carotene content; this is in agreement with the study by [12]. Whereas, the lowest mean value (4.0) was recorded for genotypes G16 and G18. These genotypes had pale yellow flesh color. Genotypes G2, G5, G6, G12, G20, G21 and G23, showed high SPVD scores with the scores of 2.0, 2.7, 3.0, 3.7, 2.3, 2.0 and 2.3, respectively, implying their susceptibility to sweetpotato virus diseases. 
The remaining genotypes showed low scores of sweetpotato sweetpotato virus disease. The finding is in agreement with virus diseases, which showed their resistance/tolerance to the work of [17].

Table 2. Mean performances for yield and yield contributing characteristics of 24 orange fleshed sweetpotato genotypes evaluated at HwARC in 2017.

\begin{tabular}{|c|c|c|c|c|c|c|c|c|c|}
\hline \multirow[b]{2}{*}{ Genotypes } & \multicolumn{9}{|l|}{ Traits } \\
\hline & RL (cm) & RG (cm) & $\begin{array}{l}\text { AGFW } \\
\left(\mathrm{t} \mathrm{ha}^{-1}\right)\end{array}$ & NRP (Kg) & $\operatorname{MRKY}\left(\mathrm{t} \mathrm{ha}^{-1}\right)$ & $\begin{array}{l}\text { UMRKY (t } \\
\left.\mathrm{ha}^{-1}\right)\end{array}$ & $\begin{array}{l}\text { TYLD (t } \\
\left.\mathrm{ha}^{-1}\right)\end{array}$ & HI (\%) & $\begin{array}{l}\text { RDMC } \\
(\%)\end{array}$ \\
\hline G1 & $18.1^{\mathrm{a}}$ & $5.1^{\text {bac }}$ & $46.2^{\mathrm{b}}$ & $0.35^{\mathrm{dec}}$ & $12.8^{\text {egdf }}$ & $3.7^{\text {ebdac }}$ & $16.5^{\text {fge }}$ & $0.26^{\text {gefdh }}$ & $31.9^{\mathrm{ba}}$ \\
\hline $\mathrm{G} 2$ & $17.4^{\text {ba }}$ & $4.5^{\text {bdac }}$ & $43.1^{\mathrm{cb}}$ & $0.32 \mathrm{dec}$ & $8^{\text {hgjfi }}$ & $0.3^{\text {ef }}$ & $8.3^{\mathrm{kji}}$ & $0.16^{\mathrm{ji}}$ & $30.9^{\mathrm{bc}}$ \\
\hline G3 & $15.8^{\text {bdac }}$ & $4.8^{\text {bdac }}$ & $45.7^{\mathrm{b}}$ & $0.54^{\text {bdac }}$ & $15.6^{\mathrm{bdc}}$ & $2.9^{\mathrm{e} \mathrm{bdfc}}$ & $18.5^{\mathrm{fdec}}$ & $0.28^{\text {gefdc }}$ & $33^{\mathrm{a}}$ \\
\hline G4 & $11.9^{\mathrm{ef}}$ & $3.4^{\mathrm{d}}$ & $46.7^{b}$ & $0.2^{\mathrm{e}}$ & $5^{j}$ & $1.7^{\mathrm{edfc}}$ & $6.8^{\mathrm{kj}}$ & $0.13^{j}$ & $30.6^{\mathrm{dc}}$ \\
\hline G5 & $15.1^{\text {ebdac }}$ & $4.3^{\text {bdac }}$ & $38.1^{\text {cebd }}$ & $0.4^{\text {bdec }}$ & $10.4^{\text {hegdfi }}$ & $1.6^{\mathrm{edfc}}$ & $11.9^{\text {gjih }}$ & $0.24^{\text {gefih }}$ & $27.9^{\mathrm{g}}$ \\
\hline G7 & $14.3^{\text {ebdac }}$ & $4.3^{\text {bdac }}$ & $31.6^{\text {fcebd }}$ & $0.3^{\mathrm{de}}$ & $7.2^{\text {hgji }}$ & $1.1^{\mathrm{edf}}$ & $8.3^{\mathrm{kji}}$ & $0.20^{\text {gifih }}$ & $28.5^{\text {feg }}$ \\
\hline G8 & $16.5^{\mathrm{bac}}$ & $4.6^{\text {bdac }}$ & $38.5^{\text {cebd }}$ & $0.6^{\text {ba }}$ & $20.7^{\mathrm{ba}}$ & $1.9^{\mathrm{edfc}}$ & $22.7^{\text {bdac }}$ & $0.37^{\text {bac }}$ & $30.3^{\mathrm{dc}}$ \\
\hline G9 & $16.9^{\mathrm{bac}}$ & $4.8^{\text {bdac }}$ & $30.8^{\text {fcebd }}$ & $0.5^{\text {bdac }}$ & $20.1^{\text {bac }}$ & $3.8^{\text {bdac }}$ & $23.9^{\text {bac }}$ & $0.44^{\text {ba }}$ & $31.5^{\mathrm{bc}}$ \\
\hline G10 & $14.5^{\text {ebdac }}$ & $5.3^{\text {bac }}$ & $33.7^{\text {cebd }}$ & $0.5^{\text {bdac }}$ & $20.1^{\text {ba }}$ & $6.5^{\mathrm{a}}$ & $27.4^{\mathrm{a}}$ & $0.45^{\mathrm{a}}$ & $31.3^{\mathrm{bc}}$ \\
\hline G11 & $15.4^{\text {ebdac }}$ & $5.1^{\text {bac }}$ & $28.8^{\text {fced }}$ & $0.5^{\text {bdac }}$ & $19.2^{\mathrm{bac}}$ & $1.4^{\mathrm{edfc}}$ & $20.6^{\text {bdec }}$ & $0.42^{\text {ba }}$ & $29.6^{\mathrm{de}}$ \\
\hline G12 & $12^{\text {edf }}$ & $3.8^{\mathrm{dc}}$ & $27.8^{\text {fced }}$ & $0.3^{\mathrm{de}}$ & $6.1^{\mathrm{ji}}$ & $2.1^{\mathrm{edfc}}$ & $8.3^{\mathrm{kji}}$ & $0.23^{\text {gefih }}$ & $30.5^{\mathrm{dc}}$ \\
\hline G13 & $16.8^{\text {bac }}$ & $5.3^{\text {bac }}$ & $40.9^{\mathrm{cbd}}$ & $0.5^{\text {bdac }}$ & $15.7^{\mathrm{bdc}}$ & $3.6^{\mathrm{e} b d a c}$ & $19.3^{\text {ebdec }}$ & $0.32^{\text {edf }}$ & $31.9^{b a}$ \\
\hline G16 & $17.2^{\text {bac }}$ & $3.8^{\mathrm{dc}}$ & $31.4^{\text {fcebd }}$ & $0.5^{\text {bdac }}$ & $11.5^{\text {hegdfi }}$ & $5.9^{\mathrm{ba}}$ & $17.4^{\text {fghe }}$ & $0.35^{\text {bdc }}$ & $30.8^{b c}$ \\
\hline G17 & $15.8^{\text {bdac }}$ & $4.8^{\text {bdac }}$ & $63.7^{\mathrm{a}}$ & $0.5^{\text {bdac }}$ & $13.4^{\text {edf }}$ & $3.1^{\mathrm{e} \mathrm{bdfc}}$ & $16.4^{\mathrm{fge}}$ & $0.20^{\text {gffih }}$ & $28.5^{\mathrm{feg}}$ \\
\hline G18 & $12.5^{\text {edf }}$ & $5.4^{\text {ba }}$ & $47.2^{b}$ & $0.3^{\mathrm{de}}$ & $9.5^{\text {hegdfi }}$ & $0.4^{\text {ef }}$ & $9.9^{\mathrm{kjih}}$ & $0.17^{\text {jih }}$ & $30.7^{\mathrm{dc}}$ \\
\hline G19 & $14.2^{\text {ebdc }}$ & $5.8^{\mathrm{a}}$ & $35.7^{\text {cebd }}$ & $0.7^{\mathrm{a}}$ & $22^{\mathrm{a}}$ & $2.6^{\mathrm{edfc}}$ & $24.6^{\text {ba }}$ & $0.41^{\text {ba }}$ & $20.1^{\mathrm{j}}$ \\
\hline G20 & $13.4^{\text {edf }}$ & $5.5^{\text {ba }}$ & $38^{\text {cebd }}$ & $0.4^{\text {bdec }}$ & $13.5^{\text {edf }}$ & $0.4^{\text {ef }}$ & $13.8^{\text {fgih }}$ & $0.27^{\text {gefdc }}$ & $29.2^{\mathrm{fe}}$ \\
\hline G21 & $16.5^{\text {bac }}$ & $5.3^{\text {bac }}$ & $47^{b}$ & $0.3^{\mathrm{dec}}$ & $6.9^{\mathrm{hji}}$ & $1.4^{\mathrm{edfc}}$ & $8.4^{\mathrm{kji}}$ & $0.15^{\mathrm{ji}}$ & $32.6^{\mathrm{a}}$ \\
\hline G22 & $14.4^{\text {ebdac }}$ & $4.9^{\text {bdac }}$ & $45.8^{\mathrm{b}}$ & $0.4^{\text {bdec }}$ & $23.5^{\mathrm{a}}$ & $1.2^{\mathrm{edfc}}$ & $24.7^{\text {ba }}$ & $0.35^{\text {bdc }}$ & $22.3^{i}$ \\
\hline G23 & $9.5^{\mathrm{f}}$ & $5.1^{\text {bac }}$ & $17.4^{f}$ & $0.3^{\mathrm{de}}$ & $5^{j}$ & $2.1^{\mathrm{edfc}}$ & $7.1^{\mathrm{kj}}$ & $0.29^{\text {efdf }}$ & $20.8^{j}$ \\
\hline G24 & $9^{f}$ & $4.4^{\text {bdac }}$ & $23.9^{\mathrm{fe}}$ & $0.2^{\mathrm{e}}$ & $5.4^{\mathrm{j}}$ & $0.2^{\mathrm{f}}$ & $5.7^{\mathrm{k}}$ & $0.19^{\text {giih }}$ & $20^{\mathrm{j}}$ \\
\hline Mean & 14.7 & 4.8 & 38.8 & 0.42 & 12.9 & 2.5 & 15.4 & 0.28 & 28.5 \\
\hline
\end{tabular}

Where, $\mathrm{RL}=$ root length, $\mathrm{RG}=$ root girth, $\mathrm{AGFW}=$ above ground fresh weight, $\mathrm{NRP}=$ number of roots per plant, $\mathrm{MRKY}=$ marketable root yield, $\mathrm{UMRKY}=$ unmarketable root yield, $\mathrm{YLD}=$ total fresh root yield, $\mathrm{HI}=$ harvest index, $\mathrm{RDMC}=$ root dry matter content

Table 3. Mean performance for morphological and qualitative traits and SPVD reaction of 24 OFSP genotypes evaluated at HwARC in 2017.

\begin{tabular}{|c|c|c|c|c|c|c|c|c|c|c|}
\hline \multirow[b]{2}{*}{ Genotypes } & \multicolumn{10}{|l|}{ Traits } \\
\hline & GC (\%) & $\begin{array}{l}\text { VL } \\
(\mathrm{cm})\end{array}$ & IL (cm) & PL (cm) & $\begin{array}{l}\text { MLS } \\
(\mathrm{cm})\end{array}$ & $\begin{array}{l}\text { VD } \\
(\mathbf{m m})\end{array}$ & $\begin{array}{l}\text { RBCC (mg100g- } \\
{ }^{{ }^{\prime}} \text { fwb) }\end{array}$ & $\begin{array}{l}\text { SC } \\
(1-9) \\
\end{array}$ & FC (1-9) & SPVD (1-5) \\
\hline G1 & $69.7^{\mathrm{hj}}$ & $113.1^{\mathrm{de}}$ & $5.2^{\text {ced }}$ & $32.9^{\mathrm{ba}}$ & $12.9^{\mathrm{bdc}}$ & $4.2^{\text {efgh }}$ & $6.2^{\mathrm{e}}$ & $2^{\mathrm{e}}$ & $7^{\text {bac }}$ & $1.7^{\text {efd }}$ \\
\hline G2 & $63.5^{\text {ihj }}$ & $126.1^{\mathrm{dc}}$ & $5.4^{\mathrm{cd}}$ & $26.4^{\mathrm{edc}}$ & $11.5^{\text {egdf }}$ & $3.3^{\mathrm{ijh}}$ & $7.5^{\mathrm{c}}$ & $4^{\mathrm{d}}$ & $6.7^{\mathrm{bc}}$ & $2^{\mathrm{ecd}}$ \\
\hline G3 & $73.3^{\mathrm{gf}}$ & $133^{\mathrm{dc}}$ & $5.7^{\mathrm{cbd}}$ & $27.7^{\mathrm{edc}}$ & $12^{\mathrm{bdc}}$ & $3.7^{\text {iefgh }}$ & $6.7^{\mathrm{de}}$ & $2^{\mathrm{e}}$ & $7^{\text {bac }}$ & $1.3^{\text {ef }}$ \\
\hline G4 & $56^{\mathrm{lkj}}$ & $193.2^{\mathrm{a}}$ & $8.3^{\mathrm{a}}$ & $16.1^{\mathrm{g}}$ & $10.3^{\text {hegf }}$ & $2.5^{\mathrm{j}}$ & $11.7^{\mathrm{a}}$ & $5^{\mathrm{c}}$ & 8 & 1.3 \\
\hline G5 & $79.7^{\mathrm{edf}}$ & $69.6^{\mathrm{gh}}$ & $4.1^{\text {fheg }}$ & $35.7^{\mathrm{a}}$ & $11.7^{\text {egdf }}$ & $4.7^{\mathrm{efcd}}$ & $7.5^{\mathrm{c}}$ & $4^{\mathrm{d}}$ & $7.7^{\mathrm{ba}}$ & $2.7^{\mathrm{bc}}$ \\
\hline G6 & $84.7^{\text {ebdac }}$ & $74.4^{\mathrm{fg}}$ & $3.7^{\text {fhig }}$ & $31.7^{\mathrm{bac}}$ & $10.7^{\text {hegf }}$ & $4.4^{\mathrm{efgd}}$ & $11.5^{\mathrm{a}}$ & $2^{\mathrm{e}}$ & $8^{\mathrm{a}}$ & $3^{\text {ba }}$ \\
\hline G7 & $57^{i \mathrm{kj}}$ & $61.2^{\text {gh }}$ & $2.9^{\mathrm{hi}}$ & $16.3^{\mathrm{g}}$ & $12.7^{\mathrm{bdc}}$ & $5.8^{\mathrm{ba}}$ & $4.6^{\mathrm{f}}$ & $6^{\mathrm{b}}$ & $7^{\text {bac }}$ & $1^{\mathrm{f}}$ \\
\hline G8 & $87.3^{\text {bdac }}$ & $84.3^{\mathrm{fg}}$ & $3.4^{\text {hig }}$ & $25.5^{\mathrm{ed}}$ & $13.8^{\text {ba }}$ & $5.2^{\text {bcd }}$ & $6.7^{\mathrm{de}}$ & $2^{\mathrm{e}}$ & $5^{\text {ed }}$ & $1^{\mathrm{f}}$ \\
\hline G9 & $84.3^{\text {ebdac }}$ & $68.4^{\mathrm{gh}}$ & $2.7^{\mathrm{ji}}$ & $23.6^{\mathrm{ef}}$ & $13.9^{\mathrm{ba}}$ & $5.5^{\mathrm{bc}}$ & $4.6^{\mathrm{f}}$ & $9^{a}$ & $7^{\text {bac }}$ & $1^{\mathrm{f}}$ \\
\hline G10 & $92.3^{\mathrm{a}}$ & $49.3^{\mathrm{h}}$ & $2.9^{\text {hig }}$ & $31.1^{\text {bac }}$ & $14.3^{\mathrm{ba}}$ & $6.5^{\mathrm{a}}$ & $4.2^{\mathrm{gf}}$ & $9^{\mathrm{a}}$ & $7^{\text {bac }}$ & 1.3 \\
\hline G11 & $88.3^{\text {bac }}$ & $67.9^{\text {gh }}$ & $3.6^{\text {fhig }}$ & $29.1^{\mathrm{bdc}}$ & $11.9^{\mathrm{edf}}$ & $4.1^{\mathrm{efgh}}$ & $10.5^{\mathrm{b}}$ & $4^{\mathrm{d}}$ & $8^{\mathrm{a}}$ & $1^{\mathrm{f}}$ \\
\hline G12 & $81^{\text {edfc }}$ & $68^{\text {gh }}$ & $3.7^{\text {fhig }}$ & $30.3^{\mathrm{bdc}}$ & $11.4^{\text {hegdf }}$ & $4.4^{\mathrm{efgd}}$ & $7.2^{\mathrm{dc}}$ & $2^{\mathrm{e}}$ & $6^{\mathrm{dc}}$ & $3.7^{\mathrm{a}}$ \\
\hline G13 & $89.7^{\text {ba }}$ & $95.4^{\mathrm{fe}}$ & $4.7^{\mathrm{fed}}$ & 33.8 & $12.9^{\mathrm{bdc}}$ & $4.2^{\text {efgh }}$ & $7.8^{\mathrm{c}}$ & $2^{\mathrm{e}}$ & $8^{\mathrm{a}}$ & $1^{\mathrm{f}}$ \\
\hline G14 & $82.7^{\mathrm{ebdc}}$ & $78.7^{\mathrm{fg}}$ & $4.1^{\text {fed }}$ & $27.5^{\mathrm{edc}}$ & $14.3^{\text {ba }}$ & $4.7^{\mathrm{ecd}}$ & $0.02^{\mathrm{h}}$ & $2^{\mathrm{e}}$ & $5.3^{\mathrm{d}}$ & $1^{\mathrm{f}}$ \\
\hline G15 & $89.7^{\text {ba }}$ & $170.6^{b}$ & $5.9^{\mathrm{cb}}$ & $26.3^{\text {edc }}$ & $10.9^{\text {hegf }}$ & $3.5^{\text {igh }}$ & $7.8^{\mathrm{c}}$ & $9^{a}$ & $8^{a}$ & $1.3^{\text {ef }}$ \\
\hline G16 & $92.7^{\mathrm{a}}$ & $79.3^{\mathrm{fg}}$ & $3.2^{\text {hig }}$ & $23.1^{\text {ef }}$ & $10.2^{\text {hgf }}$ & $3.7^{\text {iefgh }}$ & $0.02^{\mathrm{h}}$ & $6^{\mathrm{b}}$ & $4 \mathrm{f}$ & $1.3^{\text {ef }}$ \\
\hline G17 & $64.3^{\mathrm{hj}}$ & $118.3^{\mathrm{d}}$ & $4.7^{\text {fed }}$ & $29.1^{\mathrm{bdc}}$ & $14.8^{\mathrm{a}}$ & $5.5^{\mathrm{bc}}$ & $0.03^{\mathrm{h}}$ & $6^{\mathrm{b}}$ & $4^{e}$ & $1^{\mathrm{f}}$ \\
\hline G18 & $73^{\mathrm{gf}}$ & $170^{\mathrm{b}}$ & $6^{\mathrm{cb}}$ & $22.8^{\mathrm{ef}}$ & $12.7^{\mathrm{bdc}}$ & $3.7^{\text {iefgh }}$ & $0.03^{\mathrm{h}}$ & $2^{\mathrm{e}}$ & $4 \mathrm{f}$ & $1.3^{\text {ef }}$ \\
\hline G19 & $78.3^{\text {ef }}$ & $145.1^{\mathrm{c}}$ & $6.7^{b}$ & $25.3^{\mathrm{ed}}$ & $9.7^{\mathrm{h}}$ & $3.2^{\mathrm{ijh}}$ & $3.8^{\mathrm{g}}$ & $2^{\mathrm{e}}$ & $7^{\text {bac }}$ & $1.7^{\mathrm{efd}}$ \\
\hline G20 & $48.3^{1}$ & $73.6^{\mathrm{fgh}}$ & $3.7^{\text {fhig }}$ & $16.3^{\mathrm{g}}$ & $10.3^{\text {hegf }}$ & $3.9^{\text {iefgh }}$ & $4.8^{\mathrm{f}}$ & $5^{\mathrm{c}}$ & $5^{\text {ed }}$ & $2.3^{\text {bcd }}$ \\
\hline G21 & $54^{\mathrm{lk}}$ & $82.3^{\mathrm{fg}}$ & $4.1^{\text {fed }}$ & $29.9^{\mathrm{bdc}}$ & $13^{\text {bdc }}$ & $4.2^{\text {efgh }}$ & $4.6^{\mathrm{f}}$ & $2^{\mathrm{e}}$ & $7^{\text {bac }}$ & $2^{\text {bcd }}$ \\
\hline G22 & $37.7^{\mathrm{m}}$ & $85.2^{\mathrm{fg}}$ & $3.7^{\text {fhig }}$ & $23.8^{\mathrm{ef}}$ & $13.7^{\text {bac }}$ & $3.5^{\mathrm{igh}}$ & $10.5^{\mathrm{b}}$ & $5^{\mathrm{c}}$ & $8^{\mathrm{a}}$ & $1.7^{\text {efd }}$ \\
\hline G23 & $63.3^{\text {ihj }}$ & $80.1^{\mathrm{fg}}$ & $2.8^{\mathrm{ji}}$ & $19.3^{\mathrm{gf}}$ & $10.9^{\text {hegf }}$ & $4.2^{\text {efgh }}$ & $4.6^{\mathrm{f}}$ & $4^{d}$ & $7^{\text {bac }}$ & $2.3^{\mathrm{bcd}}$ \\
\hline G24 & $29^{n}$ & $63.8^{\text {gh }}$ & $1.7^{\mathrm{j}}$ & $14.5^{\mathrm{g}}$ & $10^{\mathrm{hg}}$ & $3.1^{\mathrm{ig}}$ & $4.9^{f}$ & $5^{\mathrm{c}}$ & $5^{\text {ed }}$ & $1^{\mathrm{f}}$ \\
\hline Mean & 71.6 & 97.7 & 4.3 & 25.7 & 12.1 & 4.2 & 5.7 & 4.2 & 6.4 & 1.6 \\
\hline
\end{tabular}

Where, $\mathrm{GC}=$ Ground cover, $\mathrm{VL}=$ Vine length, $\mathrm{IL}=$ Vine inter-node length, $\mathrm{VD}=$ Vine diameter, $\mathrm{PL}=$ Petiole length, MLS=Mature leaf size, $\mathrm{RBCC}=\mathrm{Root}$ beta carotene content, $\mathrm{SC}=\mathrm{Skin}$ color, $\mathrm{FC}=\mathrm{Flesh}$ color, $\mathrm{SPVD}=\mathrm{Sweetpotato}$ virus disease 
Table 4. Estimates of variance components, coefficient of variants, heritability and genetic advances of qualitative and quantitative traits and SPVD reaction for 24 OFSP genotypes evaluated at HaARC in 2017.

\begin{tabular}{|c|c|c|c|c|c|c|c|c|}
\hline \multirow{2}{*}{ Characters } & \multicolumn{2}{|c|}{ Variance components } & \multicolumn{2}{|c|}{ Coefficient of variants } & \multicolumn{2}{|c|}{ Heritability } & \multicolumn{2}{|c|}{ Genetic advances } \\
\hline & $\sigma^{2} g$ & $\sigma^{2} p$ & $\sigma^{2} \mathrm{e}$ & GCV\% & PCV\% & $\mathbf{H}^{2}(\%)$ & GA & GAM\% \\
\hline $\mathrm{GC}$ & 929.7 & 936.2 & 19.4 & 42.6 & 42.7 & 99.3 & 62.6 & 87.4 \\
\hline SPVD & 1.6 & 1.6 & 0.2 & 75.4 & 77.2 & 95.4 & 2.5 & 151.8 \\
\hline VL & 4584.6 & $4,640.3$ & 167.1 & 69.1 & 69.6 & 98.8 & 138.6 & 141.6 \\
\hline IL & 6.5 & 6.6 & 0.4 & 59.3 & 59.8 & 98.1 & 5.2 & 120.9 \\
\hline VD & 2.6 & 2.7 & 0.3 & 38.4 & 38.9 & 96.8 & 3.3 & 77.7 \\
\hline MLS & 6.9 & 7.2 & 0.9 & 21.6 & 22.1 & 96.0 & 5.3 & 43.7 \\
\hline RL & 15.2 & 16.5 & 3.9 & 26.5 & 27.6 & 92.1 & 7.7 & 53.4 \\
\hline RG & 1.0 & 1.2 & 0.6 & 20.6 & 22.5 & 83.4 & 1.9 & 38.7 \\
\hline AGFW & 457.2 & 480.9 & 71.2 & 55.1 & 56.5 & 95.1 & 42.9 & 110.6 \\
\hline HI & 0.03 & 0.03 & 0.003 & 59.5 & 60.3 & 97.2 & 0.3 & 120.9 \\
\hline RDMC & 46.2 & 46.3 & 0.4 & 23.8 & 23.8 & 99.7 & 14 & 48.9 \\
\hline $\mathrm{RBCC}$ & 35.9 & 35.9 & 0.2 & 104.4 & 104.5 & 99.8 & 12.3 & 214.9 \\
\hline Flesh & 6.2 & 9.3 & 9.3 & 39.2 & 48.02 & 66.7 & 4.2 & 66 \\
\hline NRP & 0.04 & 0.05 & 0.02 & 48.4 & 51.7 & 87.8 & 0.4 & 93.5 \\
\hline MRKY & 97.3 & 100.3 & 9.1 & 76.1 & 77.3 & 97.0 & 20.0 & 154.4 \\
\hline UMRKY & 7.7 & 8.7 & 2.9 & 111.7 & 118.3 & 89.1 & 5.4 & 217.1 \\
\hline YLD & 125.6 & 129.1 & 10.5 & 72.6 & 73.6 & 97.3 & 22.8 & 147.5 \\
\hline
\end{tabular}

$\sigma^{2} \mathrm{~g}=$ genotypic variance, $\sigma^{2} \mathrm{p}=$ phenotypic variance, $\sigma^{2} \mathrm{e}=$ environmental variance, $\mathrm{PCV}=$ phenotypic coefficient of variation, GCV=genotypic coefficient of variation, $\mathrm{H}^{2}=$ heritability in broad sense. $\mathrm{GA}=$ Genetic advance, $\mathrm{GAM}=$ Genetic advance as percent of mean

\subsection{Phenotypic and Genotypic Coefficient of Variation}

The result revealed a wide range of variability among the 24 OFSP genotypes in quantitative and qualitative traits and SPVD reaction (Table 4). For all traits studied, the magnitude of environmental variance was lower than the corresponding genotypic variance. This indicates that the genotypic component of variation was the major contributor to the total variation in the studied traits. The phenotypic coefficient of variation (PCV) was higher than the corresponding genotypic coefficient of variation (GCV). The PCV values ranged from $22.1 \%$ for mature leaf size to $118.3 \%$ for unmarketable root yield. The GCV ranged from $20.6 \%$ for root girth to $111.7 \%$ for unmarketable root yield. The lowest GCV obtained for root girth $(20.0 \%)$ while the highest GCV were observed for traits such as unmarketable root yield, root beta carotene content, skin color, marketable root yield, SPVD and total root yield, with values of $111.7,104.97 .8,76.1,75.4$ and $72.6 \%$ in that order. All the studied traits had PCV and GCV values higher than $20 \%$ (Table 4), reflecting the presence of high variability. This could be an advantage as they can offer an opportunity for selection of superior genotypes concerning the character of interest. Particularly, high GCV is an indication of the low influence of environmental factors in the expression of such traits and the higher possibility of improvements through selection and hybridization [32, 30]. Also, [1] reported high PCV and GCV values for vine length, number of storage roots per plant, individual root weight and storage root fresh weight. While, traits with low PCV and GCV values suggested the stronger influence of the environment for their expression; hence, the phenotypic basis of selection would not be effective for the improvement of the traits $[3,5]$. Also, the present study results are in agreement with that obtained by [14]. They reported considerable variances for ten storage root traits in sweet potato and a larger part was accounted for by genotypic variance. Similarly, [28] observed the maximum PCV and GCV for root yield per plant, fresh weight of root per plant and number of branches per plant, indicating the presence of wide genetic variability for morphological traits. Nevertheless, The PCV values were greater than GCV. Still, the differences between the two values were narrow; indicating the variability due to the genetic constituent of the genotypes was less influenced by environmental factors [32]. Accordingly, selection for desirable traits would be effective for sweet potato improvement.

\subsection{Estimates of Heritability}

In this study, except for one trait, almost all the traits had high broad-sense heritability, where the values ranged from 66.7 to $100 \%$ (Table 4). Indicating the traits studied was more influenced by genetic factors [23]. Accordingly, a broad sense heritability of $100 \%$ was recorded for a trait pre-dominant root skin colour. Moderate heritability was recorded for flesh color only. More than $91.1 \%$ of heritability values were obtained for almost all traits under study except root flesh color, root girth, number of roots per plant and unmarketable root yield, which indicates that these traits were less influenced by environmental factors [8]. The result is consistent with the study of [20], who reported high heritability for number of storage root per plant and storage root weight per plant in sweetpotato genotypes. However, a study by [14] suggested that in sweetpotato, a heritability estimates above $60 \%$ are quite adequate for good selection advance. Conversely, [27] 
suggested that, if heritability is less than $40 \%$, selection may be difficult or virtually impractical to improve the characters due to the masking effect of the environment on the characteristics of genotype. In general, heritability estimates alone are not of any use in predicting the results about the selection unless it is accompanied by genetic advance [14].

\subsection{Expected Genetic Advance as Percent of Mean}

In the present study, the expected genetic advance expressed as a percentage of the mean by selecting the $5 \%$ of the genotypes varied from $38.7 \%$ for root girth to $217.1 \%$ for unmarketable root yield (Table 4). This indicates that selecting $5 \%$ of high performing genotypes from the base population could result in advance of $38.7 \%$ to $217.1 \%$ over the population mean. According to Johnson et al. (1955), the genetic advance as a percent of mean is categorized as low (0 $-10 \%)$, moderate $(10-20 \%)$ and high (>20\%). Accordingly, very high expected genetic advances as a percent of mean (GAM) values were observed for unmarketable root yield (217.1), root beta carotene content (214.9), skin color (201.5), SPVD (201.5), vine length (141.6), marketable root yield (154.4), total root yield (147.5), inter-nodal length (120.9), harvest index (120.9) and above fresh ground weight (110.6) (Table 4).

High values of GAM for these traits showed that these characters are governed by additive genes and selection would be rewarding for the further improvement of such traits. Also, high heritability, along with high genetic advance, is an important factor for predicting the resultant effect for selecting the best individuals. Thus, in the present study, high heritability coupled with high GAM were observed for marketable root yield, root skin color, root beta carotene content, harvest index, vine length, vine inter-nodal length and above ground fresh weight (Table 4). Hence, high heritability along with high genetic advance is an important factor for predicting the resultant effect for selecting the best individuals $[32,28]$.

\section{Conclusion}

The significant variation among the tested genotypes revealed the presence of considerable variability for the mean performance of genotypes for vine traits, yield and its component traits as well as reaction to SPVD. Among the traits considered in this study, storage root yield, root dry matter content, root beta carotene content and reaction to SPVD were given due emphasis to select better performing genotypes. Besides, very high heritability coupled with high GAM were observed for marketable root yield, root skin color, root beta carotene content, harvest index, vine length, vine inter-node length and above ground fresh weight, implying these characters are governed by additive gene action and selection would be efficient for the further improvement of such traits. Therefore, this study demonstrated the possibility of developing high yielding OFSP varieties for release.

\section{Acknowledgements}

The authors would like to thank South Agricultural Research Institute (SARI) for financial support.

\section{References}

[1] Alam, S., Narzary, B. D. \& Deka, B. C. (1998). Variability character association and path analysis in sweet potato (Ipomea batatas (L.) Lam.). Journal of agricultural sciences Society 11 (14): 77-78.

[2] Burgos, G., Carpio, R., Sanchez, C., Sosa, P., Porras, E., Espinoza, J. \& Grüneberg, W. (2009). A colour chart to screen for high $\beta$-carotene in OFSP breeding. The $15^{\text {th }}$ Triennial Symposium of the International Society for Tropical Root Crops (ISTRC), Lima. 2-6 November, 2009. ISTRC, Lima, Peru. Pp 47-52.

[3] Chaurasia, P. C., Rajhans K. C. \& Yadav, M. (2011). Correlation coefficient and path analysis in okra (abelmoschus esculentus L.). Moench Indian Horticulture Journal 1 (1): 3236.

[4] Daniel, M. \& Loha G. 2016. Sweet Potato Agronomy Research in Ethiopia: Summary of Past Findings and Future Research Directions. Agriculture and Food Sciences Research 3 (1): $1-11$.

[5] Das, S., Chattopadhyay A., Chattopadhyay S. B., Dutta S., \& Hazra P. 2012. Genetic parameters and path analysis of yield and its components in okra at different sowing dates in the genetic plains of eastern India. African Journal of Biotechnology 11 (95): 16132-16141.

[6] Desta Beyene, 1982. Diagnosis of Phosphorus deficiency in Ethiopian Soils. Soil Science Bulletin, Institute of Agricultural research, Addis Ababa, 3: 15-18.

[7] Dudley, J. W. \& Moll R. H. 1969. Interpretation and use of estimates of heritability and genetic variances in plant breeding. Crop Science 9 (4): 257-262.

[8] Eid, M. H. 2009. Estimation of heritability and genetic advance of yield traits in wheat (Triticum aestivum L,) under drought condition. International Journal of Genetic and Molecular Biology 1 (7): 115-120.

[9] Gardner, F. P., Pearce, R. B. \& Mitchell, R. L. 1985. Physiology of Crops Plants. Iowa State University Press, Ames, IO.

[10] Gomez, K. A. \& Gomez A. A. 1984. Statistical procedures for agricultural research. Second edition. John and Sons, New York. Pp 68.

[11] Gurmu, F., Shimelis H. \& Mark L. 2017. Correlation and path-coefficient analyses of root yield and related traits among selected sweetpotato genotypes. South African Journal of Plant and Soil. DOI: 10.1080/02571862.2017.1354405.

[12] Gurmu, F., Shimelis H. \& Mark L. 2018. Combining Ability, Heterosis and Heritability of Storage Root Dry Matter, BetaCarotene and Yield-related Traits in Sweetpotato. HortScience 53 (2): 167-175.

[13] IPGRI (International Plant Genetic Resource Institute).1991. Descriptors for Sweetpotato. Rome, Italy 
[14] Jones, A., Dukes P.\% Schalk J. 1986. Sweetpotato breeding. In: Basset MJ (ed) Breeding vegetable crops, IVA, Eastport, $35 \mathrm{Pp}$.

[15] Kebede, W. T., Lemma T. \& Tadesse E. 2008. Effects of level of substitution of sweet potato (Ipomoea batatas L.) vines for concentrate on body weight gain and carcass characteristics of browsing Arsi-Bale goats. Journal of animal cell biology. 2 (2): $036-042$.

[16] Labana, K. S., Banga S. S., \& Banga, S. K. 1993. Breeding Oilseed Brassica. Indi,a Printers, New Delhi, India.

[17] Mekonnen, S., Handaro F., Gurmu F., Urage E. 2014. Sweetpotato Diseases Research in Ethiopia. International Journal of Agriculture Innovations and Research 2 (6): 23191473.

[18] Mervat, M. M., Far E., K., Mangoury E. \& Elazab H. E. M. 2009. Novel Plant Regeneration for Egyptian Sweetpotato (Ipomoea Batatas (L.) Lam.) Abees Cultivar via Indirect Organogenesis Stimulated by Initiation Medium and Cytokinin Effects. Australian Journal of Basic and Applied Sciences 3 (2): 543-551.

[19] Mohammed, A., Dechassa N., and Abebie B. 2012. Effects of planting methods and vine harvesting on shoot and tuberous root yields of sweet potato [Ipomoea batatas (L.) Lam.] in Afar region of Ethiopia. African Journal of Agricultural Research 7 (7): 1129-1141.

[20] Mok, G., Tjintokohadi N. L. \& Hoang T. D. 1997. Sweet potato breeding strategy and germplazm testing in Southeast Asia. International potato center, program report, 1995-96, Lema, Peru. Pp: 104-109.

[21] Mwanga, R. O. M., Odongo B., Niringiye C., Zhang D., Yencho G. C. \& Kapinga R. 2003. Orange fleshed sweetpotato breeding activities in Uganda. In: The 6th Conference of the African Crop Science Society (ACSS) Conference Proceeding, 12-17 October, 2003, Nairobi. African Crop Science Society, Kampala, Uganda.

[22] Mwanga, R. O. M., Yencho, G. C.,Gibson, R. W. \& Moyer, J. W. 2013. Methodology for inoculating sweetpotato virus disease: Discovery of tip dieback, and plant recovery and reversion in different clones. Plant Disease. 97: 30-36.

[23] Naidoo, S., Laurie S., Odeny D. A., Vorster B. J., Mphela W. M., Greyling M. M. \& Crampton B. G. 2016. Genetic analysis of yield and flesh colour in sweetpotato. African Crop Science Journal 24 (1): 61-73.

[24] Robinson, H. F. 1966. Quantitative genetics in relation to breeding of the centennial of mendalism. Indean Journal of Genetics 26: 171-187.

[25] Sasmita P. D., Jitendra S., Thalesh P. \& Padmakshi T. 2015. Correlation and path analysis in sweetpotato [Ipomoea batatas (L.) Lam]. Department of Vegetable Science, Indira Gandhi Krishi Viswavidyalaya, Raipur, 492012.

[26] Singh, B. D. 1993. Plant Breeding, Principles and Methods. Kalayani Publishers, New Delhi. Pp. 103-142.

[27] Singh, R. K. \& Chaudhary B. D. 1985. Biometrical Methods in Quantitative Analysis. kalayani Publishers. Environmental Ecology, 15 (1): 117-121.

[28] Solankey, S. S. Singh P. K, Singh R. K. 2015. Genetic diversity and interrelationship of qualitative and quantitative traits in sweetpotato. International Journal of Vegetable Science. 21 (3): 236-248.

[29] Tairo, F., Kullaya A. \& Valkonen. J. P. T. 2004. Incidence of viruses infecting sweetpotato in Tanzania. Plant Disease. 88: 916-920.

[30] Thiyagu, D., Rafii T. M. M., Mahmud M. A., Latif M. A., Malek, \& Sentoor G. 2013. Genetic variability of sweetpotato (Ipomoeabatatas Lam.) genotypes selected for vegetable use. Journal Food Agr. Environ. 11 (2): 340-344.

[31] Tsegaye, D., Ahmed A., Yared M., Jemal H. \& Meleaku U. 2010. Magnitude and distribution of vitamin A deficiency in Ethiopia. Ethiopian Health and Nutrition Research Institute, Addis Ababa. Food Nutrition Bulletin 31 (2): 234-241.

[32] Tsegaye, E., Sastry E. V. D. \& Dechasa N. 2006. Correlation and path analysis in sweetpotato and their implications for clonal selection. Journal of Agronomy. 5: 391-395. 